\title{
FACEBOOK TRAVEL RELATED USAGE PATTERNS OF TOURISM STUDENTS
}

\author{
Uglješa Stankov, Tamara Jovanović, Vanja Dragićević \\ University of Novi Sad, Faculty of Sciences, Department of Geography, Tourism and Hotel Management
}

\begin{abstract}
:
Facebook plays an important role as information source, communication tool and as media for sharing travel experiences. The present study will provide perspective on tourism students' travel related usage patterns of Facebook, as today's world's largest social networking platform. The purpose is to discover similarities and differences in Facebook travel related usage patterns of tourism students comparing to non-tourism students. Results of the study suggest that most similarities are present in general use of Facebook, and in non-specific travel related usage patterns. Significant differences are recorded in „core“ travel related user patterns considering posting travel related messages, content and connotation of travel related messages, content of travel related photographs and in travel specific reasons for viewing travel related photographs. It is believed that understanding differences in usage patterns in the period of higher tourism education can help students to more effectively use SNSs when dealing with travel related content in future professional life.
\end{abstract}

\author{
Key words: \\ Facebook, \\ tourism, \\ students, \\ usage patterns.
}

\section{INTRODUCTION}

Since their introduction, millions of users have been interested in social network sites (SNSs) and majority of these users have integrated such sites into their daily practices [6]. While there is a lack of a formal definition, SNSs can be generally understood as Internet-based applications that carry user generated content (UGC), which encompasses "media impressions created by consumers, typically informed by relevant experience, and archived or shared online for easy access by other impressionable consumers" [5]. SNSs exist in various forms and serve many purposes. Some of the popular SNSs include Facebook, Twitter, LinkedIn, MySpace, QZone, VKonakte, etc.

This study focuses on Facebook, as world's largest social network by the number of users [3]. On the official website, Facebook announced 1.15 billion monthly active users as of June 2013 and 699 million daily active users on average in June 2013. Facebook was launched on February 4, 2004 and has become one of the most popular websites in history. Originally, it was available only to Harvard students, then it opened to students at other colleges and universities. In September 2006, it was opened to any user with an e-mail address, 13 years old or older [2]. Facebook enables its users to present themselves using text, pictures and video, gather "friends" who can post comments on each other's pages, and view each other's profiles [14]. Some of the Facebook features important for this paper are: Profile, Status, Photos and Share. The Profile page contains all the information about users that their friends and people in their networks can see. Facebook's micro blogging feature is called "status updates" (also referred to simply as "status") which allows users to post messages for all their friends to read. Among numerous Facebook applications Photos allow users to upload albums and photographs and Share button allows content to be shared on Facebook and others. All messages on Facebook can be divided into four media types, namely, status (text only), link (text containing a URL), video (embedding a video), and photo (showing photographs) [21]. 
Researchers from various fields have examined SNSs in order to understand the practices, implications, culture, and meaning of the sites, as well as users' engagement with them [6]. In travellers' use of the Internet, SNSs have gained substantial popularity as they play an increasingly important role as information source, as communication tool during travel and as media for sharing travel experiences $[38 ; 34]$. The growing importance of SNSs for tourism is also recognized in recent academic tourism publications [e.g. 13; 30; 37; 18; 39].

Most studies have examined social media use and perceptions from consumers' perspective, because one of the major questions in tourism sector to be answered concerns what is consumers' travel related usage of SNSs. However, there is limited research addressing how tourism professionals perceive and employ social media [4]. This paper will provide perspective on tourism students' travel related usage patterns of Facebook, bearing in mind that most of the SNS users are young individuals and that many of them are university students [7]. Normally, overall social media usage statistics are useful for understand global patterns, but great differences exist among the various types of social media types and among users and creators of social media [39; 37]. The purpose of the present study is to discover Facebook travel related usage patterns of tourism students. To emphasize that usage patterns, a group of tourism students were compared to a group of non-tourism students. Research is based on the hypothesis that among tourism students travel related usage patterns of SNSs differ from other students and that tourism students will be more interested in travel related content.

This paper is of importance both for tourism education, as well as for representatives of tourism industry that create marketing campaigns through social media. Tourism students have to be aware that their use of SNSs may differ from other groups. Different usage patterns could lead to different contextual understanding of travel related content on SNSs. An important step in this process is to let students become aware of their own travel related usage patterns on SNSs in the period of their higher education, when they extensively use SNSs for various purposes. It is believed that understanding those differences can help tourism students to adjust their usage patterns in accordance with usage patterns of different group of users on SNSs.

The paper is organized as follows. The first section reviews literature pertaining to the general social media usage patterns by the student population. The second section analyses the use of social media among tourists. This is followed by an explanation of the research methodology. The subsequent section presents the findings. At last, conclusion, implication and limitation of the study are discussed.

\section{THE GENERAL USE OF SOCIAL MEDIA AMONG STUDENT POPULATION}

Millions of contemporary young adults use SNSs and, for most of them, Facebook is part of their everyday experiences [26]. In the review of research studies focusing on the use of Facebook by students and teachers, Hew [17] found out that students primarily spend between 10 and
60 min on Facebook per day. Generally, the results of past studies indicated that students had between 150 and 350 friends on Facebook. However, MarketingCharts survey from 2013 shows that Facebook age group of 18-24 in US have highest average number of Facebook friends - 510 friends. Results of previous studies regarding the level of student privacy settings on Facebook appear to be mixed. Some researchers found that students restrict their profile visibility [20;26], but other studies suggested otherwise [19].

SNSs serve a number of functions in online and offline life, such as information search, providing emotional and social support and creating and maintaining ties to other people. Hew [17] identified nine motives for Facebook use among student population. These include the following: (a) to maintain existing relationships, (b) to meet new people, (c) using Facebook is cool, fun, (d) to make oneself more popular, (e) to pass time, (f) to express or present oneself (g) for learning purposes, (h) as a task management tool and (i) for student activism. According Cheung et al. [12] most people use Facebook to get instant communication and connection with their friends. Ellison et al. [14] suggest that Facebook appears to play an important role in the process by which students form and maintain social capital. A survey of US students found evidence that the primary use of Facebook was for 'social searching' - that is, using Facebook to find out more about people whom they have met offline [22].

Facebook has been widely-adopted by students and, consequently, has the potential to become a valuable resource that supports their educational communications and collaborations with faculty [29]. Social media, in general, can help students in better preparation, stimulate project working and engage motivation and learning activities. However, there is the scarcity of education-related Facebook use among students. Selwyn [32] found that only $4 \%$ of the total of 68,169 Wall postings were related to education-use.

\section{THE USE OF SOCIAL MEDIA AMONG TOURISTS}

Customers have been increasingly using the Internet to search for travel information [4], as websites are an important source of information, across all stages of traveller's planning process. Furthermore, characteristics of online social media dramatically changed how tourists plan and consume travel related products. Social media are becoming increasingly important in travel planning, during the travel, but also in post-travel activities [13].

Social media are predominantly used during the information search stage of travel planning process. However, tourists do not only read and use information from the Internet during their choice process, but also post information on it [8]. Still, individual who collects travel information does not always have actual intention to travel. People use information for sharing with others, viewing pictures, or simply enjoying [13] and that kind of usage expands beyond functional need for information [35]. Redshift Research [28] study showed that over half 
the travellers polled worldwide used some of the social media platforms to get travel inspiration. Most of them searched for information on travel destinations (27\%), hotels $(23 \%)$, vacation activities $(22 \%)$, attractions $(21 \%)$ and restaurants (17\%). A survey in the US in 2008 showed that $91 \%$ of travellers who have read reviews online, reported that they have read a hotel review. In that same survey, travel destination reviews (85\%) follow, with restaurant reviews $(74 \%)$ and activity reviews $(60 \%)$ attracting a somewhat smaller audience.

Travellers have always engaged in storytelling to communicate tourism experiences and social media are popular means of telling the stories of one's trips supported by digital images or streaming videos. "Wired youth" stays connected to the Internet even during the travel and they continue to share their travel experience online, upon their return home [15]. According to a survey by travel search company Skyscanner carried out with 6,000 travellers in the Asia-Pacific region, $42 \%$ of the travellers are actually logging into social networks more whilst on holiday than when at home. To communicate with others about their trip, $74 \%$ of the travellers are opting for Facebook [27].

National surveys in US in 2008 and 2010 showed that travel reviews are the most prominent form of social media. Yoo and Gretzel [39] found that of those travellers who have posted reviews in US in $2008,70 \%$ have done so for hotels, while half have done so for restaurants and travel destinations [31]. There is already evidence from older studies that people put more weight on negative information than on positive information $[10 ; 8]$. However, survey in the US in 2008 showed that only $7 \%$ of travellers, who post travel-related reviews, were writing reviews that are usually negative; in contrast, $50 \%$ write reviews that are usually positive [31].

Posting and commenting photographs is frequent $\mathrm{Fa}$ cebook travel related activity. The emergence of social media has significantly changed the nature of photo-sharing by transforming personal photographs from private enjoyment to a more publicly displayable social artefact. Lo and McKercher [23] found out that Facebook is a convenient and less intrusive replacement for users to display self with less effort and thinking involved, than other means of social media. Lo et al. [23] in the analysis of usage levels of Web 2.0 photo-sharing technology of Hong Kong residents reported that SNSs were the most popular medium used, attracting almost two-thirds of the participants. An analysis of the number of likes and comments regarding Facebook messages from restaurant chains revealed that photographs and statuses receive more likes and comments than links and videos [21]. At the same time, people who post images online also tend to search for travel information from others who engage in similar activities [1]. Photographs posted by others are also frequently used as input in travel planning process [39]. In examining the types of photographs that were displayed in the Facebook albums, White [36] determined two main types of photographs: (1) photograph that includes human subjects such as the individual, family, friends, other tourists and might include a landmark or landscape in the background and (2) traditional „tourist photograph“, a visual representations of landscape, landmarks or other images such as streetscapes revealing aspects of the destination that do not include human subjects at all.

\section{METHODOLOGY}

Data for the research was collected with an online poll from 200 active Facebook users, students at the University of Novi Sad in Serbia. Student population consisted of two groups: undergraduate students of tourism (75 students) and undergraduate students of psychology (125 students). Statistical analysis of the data was computed with use of the Statistical Package for Social Sciences (SPSS 17.0 for Windows).

Online poll consisted of two sections. In the first section, general characteristics of Facebook usage were collected (General Facebook usage patterns: time spent, frequency of access, profile privacy level, number of friends; General motivation for the use of Facebook: fun, socializing and communication with friends, meeting new people for socializing, finding an intimate or sexual partner, finding and sharing information, boredom, business/ education reasons). In the second section, travel related characteristics of Facebook usage were collected using sets of six variables, including (1) time/situations when posting travel related messages to Facebook (before the travel, during the travel, right after the travel, after a certain time, when I organize my photographs/videos), (2) media types of travel related Facebook messages (photographs, videos, statuses, links), (3) content of travel related Facebook messages (travel destinations, accommodation, restaurants and food, nightlife, activities on the destination, travel agency, travel guides), (4) connotation of travel related Facebook comments (positive, negative, neutral), (5) content of travel related photographs posted on Facebook ("just me", "me with others", nature and landscape, accommodation facility, local population, restaurants and food, buildings and monuments and (6) reasons for viewing travel related photographs on Facebook (the person is important to me, travel destination is interesting, enjoying viewing nice photographs, out of boredom).

\section{RESULTS}

\section{General Facebook Usage Patterns}

To specify the differences and similarities in general usage of Facebook between the two groups of students, Mann-Whitney U test was used on three of four dependent variables from this set: time spent on Facebook, frequency of access to Facebook and Facebook profile privacy level. The results are shown in Table I.

A Mann-Whitney U Test revealed no significant difference in Facebook profile privacy levels of tourism and psychology students. A significant difference was revealed in time spent on Facebook and frequency of access to Facebook between two groups of students. Tourism students tend to spend more time on Facebook and frequency of access is higher. 
TABLE I. A COMPARISON OF VARIABLES OF GENERAL FACEBOOK USAGE OF TOURISM AND PSYCHOLOGY STUDENTS

\begin{tabular}{|c|c|r|r|r|}
\hline \multicolumn{2}{|c|}{ Group of students } & $\begin{array}{c}\text { Time } \\
\text { spent on } \\
\text { Facebook }\end{array}$ & $\begin{array}{c}\text { Fre- } \\
\text { quency of } \\
\text { access to } \\
\text { Facebook }\end{array}$ & $\begin{array}{c}\text { Facebook } \\
\text { profile } \\
\text { privacy } \\
\text { level }\end{array}$ \\
\hline \multirow{2}{*}{$N^{*}$} & Tourism & 75 & 75 & 75 \\
\cline { 2 - 5 } & Psychology & 125 & 125 & 124 \\
\hline \multirow{2}{*}{ Md*** } & Tourism & 2.00 & 4.00 & 3.00 \\
\cline { 2 - 5 } & Psychology & 2.00 & 5.00 & 3.00 \\
\hline \multicolumn{2}{|c|}{ Mann-Whitney U } & 3128.500 & 3756.000 & 4260.500 \\
\hline \multicolumn{2}{|c|}{ Z } & -4.299 & -2.404 & -1.083 \\
\hline \multicolumn{2}{|c|}{ Asymp. Sig. (2-tailed) } & 0.000 & 0.016 & 0.279 \\
\hline
\end{tabular}

$\star$ Number of respondents

** Median

An independent-samples t-test was used for continuous variable - number of Facebook friends. The results showed that there was no significant difference in scores for tourism students $(\mathrm{M}=504.50, \mathrm{SD}=325.67)$ and psychology students $(\mathrm{M}=512.42, \mathrm{SD}=375.02)(\mathrm{t}(197)=$ -1.51, $\mathrm{p}=0.88$, two-tailed).

TABLE II. A COMPARISON OF VARIABLES OF GENERAL MOTIVATION FOR THE USE OF FACEBOOK BETWEEN TOURISM ( $\mathrm{N}=75)$ AND PSYCHOLOGY STUDENTS $(\mathrm{N}=125)$

\begin{tabular}{|c|c|c|c|c|c|}
\hline \multirow{2}{*}{$\begin{array}{l}\text { Variables of } \\
\text { general moti- } \\
\text { vation }\end{array}$} & \multicolumn{2}{|c|}{ Md* } & \multirow{2}{*}{$\begin{array}{c}\text { Mann- } \\
\text { Whitney U }\end{array}$} & \multirow{2}{*}{ Z } & \multirow{2}{*}{$\begin{array}{l}\text { Asymp. Sig. } \\
\text { (2-tailed) }\end{array}$} \\
\hline & $\mathrm{T}^{* *}$ & $\mathbf{P} * * *$ & & & \\
\hline Fun & 3.00 & 4.00 & 6585.500 & -2.448 & 0.014 \\
\hline $\begin{array}{l}\text { Socializing } \\
\text { and commu- } \\
\text { nication with } \\
\text { friends }\end{array}$ & 2.00 & 2.00 & 7291.500 & -0.648 & 0.517 \\
\hline $\begin{array}{l}\text { Meeting new } \\
\text { people for } \\
\text { socializing }\end{array}$ & 5.00 & 5.00 & 11932.000 & -1.620 & 0.105 \\
\hline $\begin{array}{l}\text { Finding an } \\
\text { intimate or } \\
\text { sexual partner }\end{array}$ & 7.00 & 7.00 & 11911.000 & -1.861 & 0.063 \\
\hline $\begin{array}{l}\text { Finding and } \\
\text { sharing infor- } \\
\text { mation }\end{array}$ & 3.00 & 3.00 & 12422.000 & -0.362 & 0.718 \\
\hline Boredom & 4.00 & 4.00 & 7394.500 & -0.366 & 0.714 \\
\hline $\begin{array}{l}\text { Business } \\
\text { reasons }\end{array}$ & 5.00 & 5.00 & 12055.000 & -1.298 & 0.194 \\
\hline
\end{tabular}

* Median

${ }_{* *}^{*}$ Tourism students

*** Psychology Students

No significant difference in variables of general motivation for the use of Facebook was revealed by A MannWhitney $U$ test, except in case of fun as a motivation (Table II). Fun as a motivation is more important to tourism students (Md rank 3) than to psychology students ( $\mathrm{Md}$ rank 4)

\section{Facebook Travel Related User Patterns}

To specify the differences and similarities in Facebook travel related user patterns between two groups of students, T-test was conducted on three dependent sets of variables: time of posting and preferred media types, content and connotation of travel related messages and comments and content of travel related photographs and reasons for viewing them.

TABLE III. A COMPARISON OF VARIABLES OF TIME AND PREFERRED MEDIA TYPES OF FACEBOOK TRAVEL RELATED MESSAGES BETWEEN TOURISM AND PSYCHOLOGY STUDENTS (N- NUMBER OF RESPONDENTS; M- MEAN; SD - STANDARD DEVIATION)

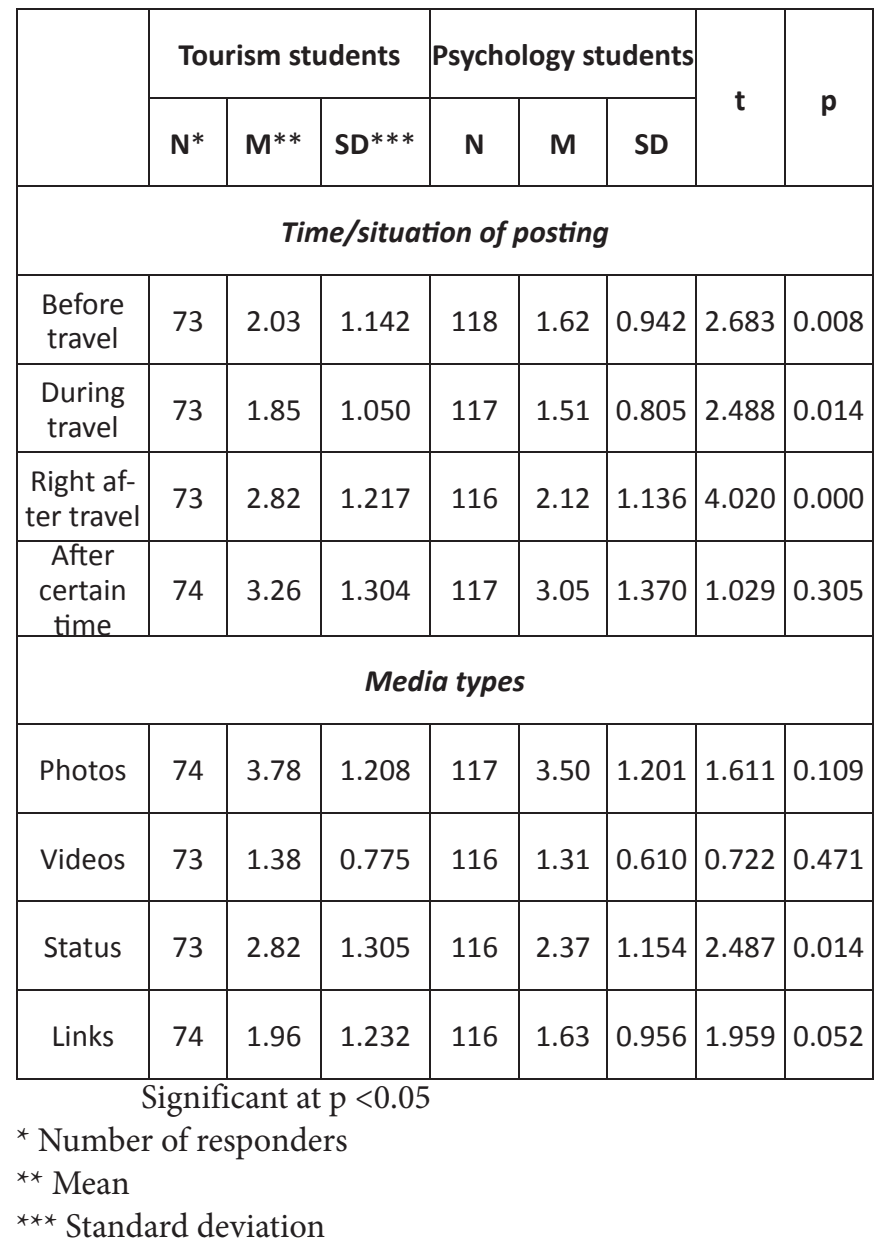

The results for first set of variables are shown in Table III. The results indicated that there are significant mean differences for three out of four variables in variable set „time/situation of posting" between the tourism and psychology students. Both groups of students post travel related messages after a certain time when they organize photographs/videos and for this variable there were no significant mean differences. However, tourism students assign higher ratings to the time before, during and after travel to post travel related messages than psychology students indicating they are more active on Facebook in all three phases of travel.

As it can be seen in Table III, there are no significant mean differences in preferred media type of Facebook travel related messages between two groups of students, 
except in the case of posting statuses. Both groups of students prefer photographs as media type for posting travel related messages on Facebook. Photographs are followed by statuses, but tourism students tend to used them more often than psychology students. Both groups of students assigned low values to links and videos as media types for posting travel related messages.

TABLE IV. A COMPARISON OF VARIABLES OF CONTENT AND CONNOTATION OF TRAVEL RELATED MESSAGES AND COMMENTS ON FACEBOOK BETWEEN TOURISM AND PSYCHOLOGY STUDENTS (DESTN - DESTINATION, ACCOMM - ACCOMMODATION, RESTT - RESTAURANT)

\begin{tabular}{|c|c|c|c|c|c|c|c|c|}
\hline & \multicolumn{3}{|c|}{ Tourism students } & \multicolumn{3}{|c|}{ Psychology students } & \multirow{2}{*}{$\mathrm{t}$} & \multirow{2}{*}{$p$} \\
\hline & $\mathrm{N}^{*}$ & $\mathrm{M}^{* *}$ & $\mathrm{SD} * * *$ & N & $\mathrm{M}$ & SD & & \\
\hline \multicolumn{9}{|c|}{ Content } \\
\hline $\begin{array}{l}\text { Travel } \\
\text { destn. }\end{array}$ & 74 & 3.57 & 1.272 & 117 & 2.79 & 1.285 & 4.108 & 0.000 \\
\hline Accomm. & 71 & 2.25 & 1.317 & 116 & 1.46 & 0.785 & 4.619 & 0.000 \\
\hline Restt. & 74 & 2.35 & 1.297 & 117 & 1.56 & 0.914 & 4.603 & 0.000 \\
\hline Night life & 73 & 3.21 & 1.384 & 116 & 2.73 & 1.410 & 2.260 & 0.025 \\
\hline Activities & 73 & 3.42 & 1.413 & 115 & 2.74 & 1.292 & 3.418 & 0.001 \\
\hline $\begin{array}{l}\text { Travel } \\
\text { agency }\end{array}$ & 74 & 1.69 & 0.950 & 116 & 1.20 & 0.578 & 3.999 & 0.000 \\
\hline $\begin{array}{l}\text { Travel } \\
\text { guides }\end{array}$ & 74 & 1.65 & 0.943 & 116 & 1.29 & 0.746 & 2.742 & 0.007 \\
\hline \multicolumn{9}{|c|}{ Connotation } \\
\hline positive & 74 & 3.84 & 1.272 & 117 & 3.40 & 1.273 & 2.307 & 0.022 \\
\hline negative & 73 & 2.89 & 1.420 & 117 & 2.28 & 1.217 & 3.142 & 0.002 \\
\hline neutral & 72 & 2.00 & 1.222 & 117 & 1.90 & 1.062 & 0.609 & 0.544 \\
\hline
\end{tabular}

Significant at $\mathrm{p}<0.05$

${ }^{\star}$ Number of responders

** Mean

$* * *$ Standard deviation

The results of t-test on the set of variables for content and connotation of travel related messages and comments are shown in Table IV. The results indicate that there is significant mean difference for all of seven variables in content of travel related messages and comments between the tourism and psychology students. Tourism students post more of these travel specific messages and comments. Most commented variables in both of the groups are travel destinations, activities on the destination and night life, then restaurants and accommodation, and lastly travel agencies and tour guides.
TABLE V. A COMPARISON OF VARIABLES OF CONTENT OF TRAVEL RELATED PHOTOGRAPHS AND OF REASONS FOR VIEWING TRAVEL RELATED PHOTOGRAPHS ON FACEBOOK BETWEEN TOURISM AND PSYCHOLOGY STUDENTS (DESTN - DESTINATION, ACCOMM - ACCOMMODATION, RESTT - RESTAURANT)

\begin{tabular}{|c|c|c|c|c|c|c|c|c|}
\hline \multirow{2}{*}{ Variables } & \multicolumn{3}{|c|}{ Tourism students } & \multicolumn{3}{|c|}{$\begin{array}{l}\text { Psychology stu- } \\
\text { dents }\end{array}$} & \multirow{2}{*}{$t$} & \multirow{2}{*}{$\mathbf{p}$} \\
\hline & $\mathbf{N}^{*}$ & $\mathbf{M}^{* *}$ & SD*** & $\mathbf{N}$ & $\mathbf{M}$ & SD & & \\
\hline \multicolumn{9}{|c|}{ Content of photographs } \\
\hline Just me & 74 & 2.08 & 0.807 & 115 & 2.12 & 0.637 & -0.385 & 0.701 \\
\hline Me with others & 74 & 3.20 & 0.936 & 116 & 3.17 & 0.944 & 0.216 & 0.829 \\
\hline $\begin{array}{l}\text { Nature and } \\
\text { landscapes }\end{array}$ & 73 & 2.67 & 0.898 & 116 & 2.39 & 0.862 & 2.164 & 0.032 \\
\hline $\begin{array}{l}\text { Buildings and } \\
\text { monuments }\end{array}$ & 71 & 2.66 & 0.940 & 117 & 2.32 & 0.934 & 2.454 & 0.015 \\
\hline $\begin{array}{l}\text { Accomm. } \\
\text { facilities }\end{array}$ & 73 & 1.77 & 0.755 & 116 & 1.48 & 0.611 & 2.840 & 0.005 \\
\hline Restt. and food & 72 & 1.85 & 0.744 & 116 & 1.54 & 0.677 & 2.881 & 0.004 \\
\hline $\begin{array}{l}\text { Local popula- } \\
\text { tion }\end{array}$ & 73 & 1.75 & 0.722 & 115 & 1.46 & 0.704 & 2.748 & 0.007 \\
\hline \multicolumn{9}{|c|}{ Reasons for viewing } \\
\hline $\begin{array}{c}\text { Person is impor- } \\
\text { tant to me }\end{array}$ & 75 & 4.11 & 1.122 & 124 & 3.99 & 1.055 & 0.726 & 0.469 \\
\hline $\begin{array}{c}\text { Travel destn. is } \\
\text { interesting }\end{array}$ & 75 & 4.55 & 0.741 & 123 & 4.09 & 0.958 & 3.537 & 0.001 \\
\hline $\begin{array}{l}\text { Enjoying view- } \\
\text { ing nice photos }\end{array}$ & 75 & 4.28 & 0.909 & 122 & 3.70 & 1.098 & 3.859 & 0.000 \\
\hline Out of boredom & 75 & 2.89 & 1.110 & 124 & 2.94 & 1.258 & -0.294 & 0.769 \\
\hline \multicolumn{9}{|c|}{ Significant at $\mathrm{p}<0.05$} \\
\hline \multicolumn{9}{|c|}{ * Number of responders } \\
\hline \multicolumn{9}{|c|}{${ }^{*}$ Mean } \\
\hline \multicolumn{9}{|c|}{$\star * *$ Standard deviation } \\
\hline
\end{tabular}

Significant mean differences between two groups of students are present in positive and negative connotation of travel related messages. Tourism students assigned higher ratings on positive and negative connotations. Results of t-test show no significant mean differences for neutral connotations between two groups of students.

In terms of "content of travel related photographs“ t-test results show there are no significant mean differences for "just me" and "me and others" variables between two groups of students (Table V). However, significant mean differences are present for photographs representing nature and landscapes, buildings and monuments, accommodation facilities, restaurants and food and local population. Tourism students post photographs with this content more frequently than psychology students. In both groups, the most common are photographs of students with others, photographs of nature and landscape and building and monuments. 
The most frequent reason for viewing travel related photographs for both groups of students is interest for travel destination (Table V). However, there are significant mean differences between two groups of students. For tourism students this is a more frequent reason. Significant mean differences are also recorded in „enjoying viewing nice photographs" variable. For tourism students this is also a more frequent reason, and at the same time the second frequent reason for viewing travel photographs, while for psychology student „person is important for me" variable is the second frequent reason. For this variable there are no significant differences between two groups of students, as well as for "out of boredom" variable.

\section{DISCUSSION AND CONCLUSIONS}

The results of the study found significant differences between tourism and psychology students in term of Facebook travel related usage patterns. Most similarities are obvious in general use of Facebook, and in non-specific travel related usage patterns. Significant differences are recorded in „core“ travel related user patterns considering posting travel related messages in all stages of travel, content and connotation of travel related messages, content of travel related photographs and in travel specific reasons for viewing travel related photographs on Facebook. However, there were no significant difference in Facebook media types of travel related messages, neutral comments, or in variables "just me" or "me with others" in content of travel related photographs.

These differences could indicate that Facebook travel related usage patterns of tourism students are influenced by their tourism educational orientation, that is, their interest in this topic. Results clearly show that tourism students more frequently post and interact with travel specific content on Facebook. Whatever the reason for the differences, this study indicates that more research should be conducted to determine how to better understand specific user patterns of tourism students on SNSs. Since, their travel related usage patterns on SNSs may differ from the others, students must be aware of that fact in order to correctly adjust and anticipate behaviour of their customers. For example, the findings of Park et al. [25] suggest that the availability of the reviewer's self-disclosed personal profile information serves as credibility cues for travellers' assessments of travel reviewers. Considering this, as future tourism professionals, tourism students should consider having less restrict Facebook's Profile privacy in order to transfer more trustful Facebook tourism messages. In addition, nowadays, large amount of travel related content on SNSs is generated by tourists. The role of travel professionals on SNSs is less and less about creation, and more and more about digital curation. In that context, one of the most important tasks of travel professionals is to manage travel related content on SNSs correctly, guided by users' patterns.

Due to the changing nature of social media and tourism industry's reaction to it, this kind of research may not be completed in just one study. Discovering the usage pat- terns of SNSs might be useful in making decisions about the design and implementation of those applications as well as educational tools [7]. SNSs, intentionally or not, are becoming integrated part of tourism education. Particular attention should be paid to providing students with instructions on how to interact with content and with each other in online learning environments. Lee and Wicks [11] explored the effectiveness of social media for delivering technology training to destination marketing professionals.

This field of investigation is at an iterative stage where empirical models and frameworks are just emerging. This study contributes an understanding of Facebook travel related usage patterns addressing an academic gap in the literature in examining tourism students. Though this research provides insight into students' usage patterns, it is by design limited to a population and sample of Serbian students and to predefined types of Facebook travel related usage patterns that may not be representative of entire student population and all possible ways of usage patterns. However, we believe that sample of Serbian tourism students reasonably represents average Facebook's student user, bearing in mind general Facebook usage patterns. For this reasons, the current study needs to be considered as not the last stage to complete understanding of Facebook travel related usage patterns of tourism students, but rather a first step.

\section{REFERENCES}

[1] G. Akehurst, "User generated content: the use of blogs for tourism organisations and tourism consumers," Service Business, vol. 3(1), 2009, pp. 51-61.

[2] J. Alba and J. Stay, "I'm on Facebook - now what??? How to get personal, business, and professional value from Facebook". Silicon Valley: Cupertino: HappyAbout.info, 2008.

[3] C. Arno, "Worldwide Social Media Usage Trends in 2012". Accessed on June 2012.

http://searchenginewatch.com/article/2167518/WorldwideSocial-Media-Usage-Trends-in-2012.

[4] J.K. Ayeh, D. Leundg, N. Au and R. Law, "Perceptions and Strategies of Hospitality and Tourism Practitioners on Social Media: An Exploratory Study," in Information and Communication Technologies in Tourism 2012, Proceedings of the International Conference in Helsinborg, Sweeden, January 25-27, 2012, M. Fuchs, F. Ricci, L. Cantoni, Eds. Mörlenbach: Springer-Verlag, 2012, pp. 1-12.

[5] P. Blackshaw, "The Consumer-Generated Surveillance Culture," Accessed on August 12009.

http://www.clickz.com/showPage.html?page=3576076.

[6] D.M. Boyd and N.B. Ellison, "Social Network Sites: Definition, History, and Scholarship," Journal of Computer-Mediated Communication, vol 13 (1), pp. 210 - 230, 2007.

[7] A.S. Bozkır, S. Güzin Mazman and E. Akçapınar Sezer, "Identification of User Patterns in Social Networks by Data Mining Techniques: Facebook Case," in Technological Convergence and Social Networks in Information Management Communications in Computer and Information Science Volume 96, S. Kurbanoğlu, U. Al, P. L. Erdoğan, Y. Tonta and N. Uçak, Eds. Berlin Heidelberg: Springer, 2010, pp. 145-153. 
[8] F. Bronner and R. de Hoog, "Vacationers and eWOM: Who Posts, and Why, Where, and What?, Journal of Travel Research, vol. 50(1), pp.15-26, 2011.

[8] D. Buhalis and R. Law, "Progress in information technology and tourism management: 20 years on and 10 years after the Internet - The state of eTourism research," Tourism Management, vol. 29 (4), pp. 609-623, 2008.

[10] F.A. Buttle, "Word of Mouth: Understanding and Managing Referral Marketing," Journal of Strategic Marketing, vol. 6, pp. 241-54, 1998

$[1,1]$ B.C. Lee and B. Wicks, "Tourism technology training for destination marketing organisations (DMOs): Need-based content development," Journal of Hospitality, Leasure, Sport and Tourism Education, vol. 9(1), pp. 39 - 52, 2010.

[12] C.M.K. Cheung, P.Y. Chiu and M.K. O. Lee, "Online social networks: Why do students use facebook?," Computers in $\mathrm{Hu}-$ man Behavior, vol 27, pp. 1337-1343, 2011.

[13] Y.Chung and D. Buhalis, "Information Need in Online Social Networks,” Information Technology \& Tourism, vol. 10 (4), pp. 267-281, 2008.

[14] N.B. Ellison, C. Steinfield and Lampe, C. "The Benefits of Facebook "Friends:" Social Capital and College Students' Use of Online Social Network Sites," Journal of Computer-Mediated Communication, vol. 12, pp. 1143-1168, 2007.

[15] U. Gasser and M. Simun, "Digital Lifestyle and Online Travel: Looking at the Case of Digital Natives," in Trends and Issues in Global Tourism, R. Conrady, M. Buck, Eds. Berlin Heidelberg: Springer-Verlag, 2010, pp. 83-89.

[16] J. Graham, A. Faix and L. Hartman, "Crashing the Facebook party,” Library Review, vol. 58(3), pp. 228-236, 2009.

[17] K.F. Hew, "Students' and teachers' use of Facebook," Computers in Human Behavior, vol. 27, pp. 662-676, 2011.

[18] Y.L. Hsu, "Facebook as international eMarketing strategy of Taiwan hotels," International Journal of Hospitality Management, vol. 31, pp. 972- 980, 2012.

[19] A.N. Joinson, “'Looking at', 'Looking up' or 'Keeping up with' people? Motives and uses of facebook," in Proceedings of the 26th annual SIGCHI conference on human factors in computing systems, New York: ACM, 2008, pp.1027-1036,

[20] E.A. Kolek and D. Saunders, "Online disclosure: An empirical examination of undergraduate facebook profiles," NASPA Journal, vol. 45(1), pp. 1-25, 2008.

[21] L. Kwok and B. Yu, "Spreading Social Media Messages on Facebook: An Analysis of Restaurant Business-to-Consumer Communications," Cornell Hospitality Quarterly, vol. 20 (10), pp. 1-11, 2012.

[22] C. Lampe, N. Ellison and C. Steinfield, "A Face(book) in the Crowd: Social Searching vs. Social Browsing," in Proceedings of ACM Special Interest Group on Computer-Supported Cooperative Work, New York: ACM Press, 2006, pp. 167 - 170.

[23] I.S. Lo and B. McKercher, "The Production and Consumption of Online Travel Photography: An Analytical Framework," Proceedings of the APTA conference July 13 - 16, 2010, Macao, China, pp. $81-85$.

[24] I. S. Lo, B. McKercher, A. Lo, C. Cheung and R. Law, “Tourism and online photography," Tourism Management, vol. 32 (4), pp. 725-731, 2011.

[25] H.L. Park, Z. Xiang, B. Josiam and H.M. Kim, "Personal Profile Information as Cues of Credibility in Online Travel Reviews," in Information and Communication Technologies in Tourism
2013 Proceeding of the International Conference in Innsbruck, Austria, January 22-25, 2013, L. Cantoni, Z. Xiang, Eds. Berlin: Springer, 2013, pp. 230-241.

[26] T.A. Pempek, Y. Yermolayeva and S. Calvert, "College students' social networking experiences on Facebook," Journal of Applied Developmental Psychology, vol. 30(3), pp.227-238, 2009.

[27] K. Prabu, "Indians fail to leave social networks at home when travelling," Accessed June 4. 2013.

http://www.tnooz.com/2013/04/24/news/indiansfail-to-leave-social-networks-at-home-when-travelling/\#tGHZM4Q7Jsm5amRl.99

[28] Redshift Research, “Text100 Digital Index: Travel \& Tourism Study," Redshift Research. Accessed July 10. 2012http://info. text100.com/Portals/162056/docs/Text100DigitalIndexTravelTourismStudTOP10Final.pdf.

[29] M.D. Roblyer, M. McDaniel, M. Webb, J. Herman and J. V. Witty, "Findings on Facebook in higher education: A comparison of college faculty and student uses and perceptions of social networking sites," The Internet and Higher Education, vol. 13 (3), pp.134-140, 2010.

[30] R. Schegg, A. Liebrich, M. Scaglione and S. Ahmad, "An Exploratory Field Study of Web 2.0 in Tourism”, in Information and communication technologies in tourism 2008 Proceedings of the international conference in Innsbruck, Austria 2008, P. O'Connor, W. Höpken and U. Gretzel, Eds. Wien; New York: Springer. 2008, pp. 152-163.

[31] C. Schetzina, "The PhoCusWright Consumer Technology Survey Second Edition," in Trends and Issues in Global Tourism 2009, R. Conrady and M. Buck, Eds. Berlin: Springer. 2009, pp. 113-133.

[32] N. Selwyn, "Faceworking: Exploring students' education-related use of Facebook," Learning, Media and Technology, vol. 34(2), pp. 157-174, 2009.

[33] A.B. Serwin, "Social Media: Understanding User Patterns and Compliance Issues," The Lares Institute; Foley \& Lardner LLP, 2011, Accessed on June 9. http://ssrn.com/abstract=1859443.

[34] M.D. Sotiriadis, and C.van Zyl, "Electronic word-of-mouth and online reviews in tourism services: the use of twitter by tourists," Electronic Commerce Research, vol. 13, pp. 103-124, 2013.

[35] CA. Vogt and D.R. Fesenmaier, "Expanding the functional information search model," Annals of Tourism Research, vol. 25(3), pp. 551-578, 1998.

[36] L. White, "Facebook, Friends and Photos: A Snapshot into Social Networking for Generating Travel Ideas," in Tourism Informatics: Visual Travel Recommender Systems, Social Communities, and User Interface Design, N. Sharda, Ed. Hershey: Information Science Reference. 2009, pp. 115-129.

[37] A. Wilson, H. Murphy and J. C. Fierro, "Hospitality and Travel: The Nature and Implications of User-Generated Content," Cornell Hospitality Quarterly,” vol. 53(3), pp. 220-228, 2012.

[38] Z. Xiang and U. Gratzel, "Role of social media in online travel information search," Tourism Management, vol. 31 (2), pp. 179-188, 2010.

[39] K. Yoo and U. Gretzel, "Use and Creation of Social Media by Travellers," in Social Media in Travel, Tourism and Hospitality: Theory, Practice and Cases, M. Sigala, E. Christou, U. Gretzel, Eds. Farnham: Ashgate, 2012, pp. 189-205. 